https://nv.nltu.edu.ua

https://doi.org/10.36930/40300117

\title{
ЦИКЛІЧНІ ЗАКОНОМІРНОСТІ РОЗВИТКУ МАКРОЕКОНОМІЧНИХ СИСТЕМ
}

Розглянуто циклічні закономірності розвитку макроекономічних систем. Здійснено науковий аналіз і узагальнення поглядів представників кейнсіанства і неоконсерватизму на основні проблеми сучасної економічної теорії та практики, розкрито їхній внесок у розвиток економічної науки і формування економічної політики провідних держав світу й України, підходи до класифікації економічних систем. Висвітлено авторське припущення, що "неокейнсіанська концепція пояснення причин макроекономічних коливань $€$ найкращою поміж інших теорій". Зазначено, що в сучасних дослідженнях науковці намагаються поєднати в одній моделі механізми поширення макроекономічної нестабільності як щодо попиту, так і щодо пропозиції. Тобто відбувається синтез неокейнсіанської та неокласичної концепцій. Проте цей синтез неокейнсіанських та неокласичних моделей також не дає змоги відтворити всі явища бізнес-циклу. В обох концепціях наявні фундаментальні припущення, які не дають змоги правильно змоделювати макроекономічну систему. Зроблено висновок, що однією 3 причин недосконалості цих моделей є практика моделювання функцій корисності домогосподарств, яка виходить 3 концепції раціональності вибору макроекономічного агента. Сьогодні економічна наука не може чітко пояснити, змоделювати і спрогнозувати кризові явища в макроекономічних системах. Тому проведений нами аналіз літературних джерел показав, що не варто розраховувати на якісь детерміновані закономірності розвитку макроекономічних систем. Відповідно макроекономічне регулювання змушене мати адаптивний і стабілізаційний (контрциклічний) характери.

Ключові слова: макроекономічна система; екоекономічне регулювання; ринковий механізм; фінансово-економічна криза.

Вступ. Парадигми неоконсерватизму і кейнсіанства серед сучасних моделей розвитку економічної науки були визначальними в економічній теорії XX ст. і на початку XXI ст., а постулати, сформульовані представниками цих напрямів економічної думки, стали теоретичним підгрунтям подолання кризових явищ у провідних державах із розвиненою ринковою економікою, починаючи з другої третини XX ст. і до сьогодні.

Тому, зважаючи на важливість визначення шляхів подальшого соціально-економічного розвитку, важливого значення набуває дослідження циклічних закономірностей розвитку макроекономічних систем для всебічного врахування історико-економічної спадщини з іiі досягненнями та прорахунками в майбутньому.

Об'єкт дослідження - циклічні закономірності розвитку макроекономічних систем.

Предмет дослідження - методи і засоби визначення циклічних закономірностей розвитку макроекономічних систем, які сукупно дадуть змогу здійснити їх класифікацію.

Мета дослідження - розглянути питання щодо аналізу й узагальнення поглядів представників кейнсіанства і неоконсерватизму на основні проблеми сучасної економічної теорії та практики, розкрити їхній внесок у розвиток економічної науки і формування економічної політики провідних держав світу й України, підходи до класифікації економічних систем.

Для досягнення зазначеної мети потрібно виконати такі основні завдання дослідження:

- провести аналіз літературних джерел, що дасть змогу пояснити причини макроекономічних коливань;

- з'ясувати причини недосконалості наявних підходів до моделювання функцій корисності домогосподарств, яка виходить 3 концепції раціональності вибору макроекономічного агента;

- пояснити, змоделювати і спрогнозувати кризові явища в макроекономічних системах.

Методи дослідження. Під час проведення дослідження використовували такі методи: метод спостережень (для аналізу й узагальнення поглядів представників кейнсіанства і неоконсерватизму на основні проблеми сучасної економічної теорії та практики); методи економічного аналізу (для оцінювання механізмів поширення макроекономічної нестабільності).

Аналіз останніх публікацій і досліджень. Питання, які стосуються дослідження циклічних закономірностей розвитку макроекономічних систем, з'ясовували такі вчені, як: О. Я. Базілінська [1], Л. В. Білецька [2], R. Dornbusch [3], C. Edward [9], М. О. Жук [5], Н. Д. Кондратьев [6], Р. R. Krugman [7], L. H. Summers [12], O. Landmann [8], Л. В. Проданова [10], J. Schumpeter [11], J. B. Taylor [13], D. Hendry [4] та ін.

Викладення основного матеріалу. Макроекономічна система - це сукупність економічних суб'єктів країни, діяльність яких відбувається в умовах конкретноісторичних виробничих відносин та адекватних їм механізмів регулювання економіки [10]. Макроекономіч-

Інформація про авторів:

Кітц Рудольф Рудольфович, здобувач, кафедра туризму та готельно-ресторанної справи. Email: iraan@ukr.net

Цитування за ДСТУ: Кітц Р. Р. Циклічні закономірності розвитку макроекономічних систем. Науковий вісник НлтУ України. 2020, т. 30, № 1. C. 99-103.

Citation APA: Kitc, R. R. (2020). Cyclic conformities to law of development of macroeconomic systems. Scientific Bulletin of UNFU, 30(1), 99-103. https://doi.org/10.36930/40300117 
ну систему можна зобразити у вигляді взаємодії чотирьох суб'єктів: сектора домашніх господарств, підприємницького сектора, держави та закордону - на чотирьох ринках: благ, праці, грошей і цінних паперів [1]. Переважна більшість сучасних макроекономічних систем $\epsilon$ відкритими, що означає їхній зв'язок з економічними системами інших країн.

В економічній літературі існують різні підходи до класифікації економічних систем. Наукове узагальнення суспільного розвитку дає підстави стверджувати, що окремі економічні системи здебільшого різняться між собою за такими ознаками: за формами власності на засоби виробництва; за механізмами координації (регулювання) економічної діяльності. Спираючись на ці ознаки, можна виділити такі типи макроекономічних систем: ринкову економіку, командно-адміністративну, змішану економіку. У сучасному світі панує змішана економіка, яка поєднує в собі різні форми власності (приватну, колективну, державну) та два головні механізми регулювання економічної діяльності (ринковий і державний). Саме змішана економічна система i $\epsilon$ сьогодні об'єктом дослідження макроекономіки [1].

Якщо виходити з класичної концепції, що ринковий механізм здатний забезпечити стабільний саморегулюючий розвиток макроекономічної системи, тоді необхідно опиратися на поняття самоорганізації, яке використовується в синергетиці. Згідно зі синергетичними підходами до дослідження відкритих систем, самоорганізація не уникає фазових переходів і біфуркацій в самій системі, тобто не можна говорити про стабільність системи. Однак, концепція регулюючої сили ринкового механізму має своїх прибічників серед економістів-науковців та практиків, що відображається на державному механізмі регулювання економічної діяльності. Прихильники ринкового механізму дотримуються монетаристських підходів у державному регулюванні макроекономічних систем. Ті ж науковці та практики, які розуміють неспроможність ринкового механізму в довготерміновій перспективі забезпечити стабільність макроекономічної системи, дотримуються кейнсіанських підходів у державному регулюванні макроекономічних систем. При цьому під стабільністю макроекономічної системи розуміємо такий ii стан, при якому забезпечується максимальний рівень зайнятості і економічне зростання. 3 погляду теорії систем, ринковий механізм може забезпечити стабільність макроекономічної системи у певному фазовому стані. Наприклад, економіка може тривало перебувати у стані стагнації, що є стабільним станом, оскільки основні параметри макроекономічної системи залишаються незмінними (стабільними). Збалансована макроекономічна система може характеризуватися високим рівнем безробіття, низьким рівнем товарообігу, відсутністю інфляції. 3 погляду кейнсіанської концепції, такий стан макроекономічної системи не є стабільним, оскільки призводить до негативних соціальних, демографічних та політичних наслідків, що в довготерміновій перспективі дестабілізує економіку і посилить зниження виробництва та споживання.

Для кейнсіанців важливими є механізми взаємодії держави та макроекономічної системи в парадигмі суб'єкта та об'єкта управління. Суб'єктом управління виступає держава, а об'єктом управління - суб'єкти макроекономічної системи та взаємозв'язки між ними. В межах цієї парадигми для аналізування макроекономічних систем доцільно скористатися кібернетичними підходами та теорією управління. Згідно 3 кібернетикою, щоб сформувати управлінські сигнали, які можуть переводити об'єкт управління у прогнозований і запланований стан, необхідно мати точну математичну модель об'єкта управління. Також треба враховувати, що в національному господарстві країни середнього розміру функціонують мільйони домогосподарств, тисячі фірм, десятки банків. Тому велика кількість елементів макроекономічної системи не дають змоги сформувати точну математичну модель системи. Відповідно не можливо розробити управлінські впливи на макроекономічну систему, які матимуть детермінований вплив на неї. Управління макроекономічною системою може мати лише адаптивний характер, тобто управлінські впливи повинні підлаштовуватися під реакцію макроекономічної системи на попередні управлінські дії держави. М. О. Жук [5] зазначає, що система домогосподарств на макроекономічному рівні успішно функціонує в навколишньому середовищі завдяки пристосованості та узгодженості $з$ ним. Основними характерними рисами зовнішнього середовища системи домогосподарств $\epsilon$ його складність, рухомість та невизначеність. Складність навколишнього середовища виявляється через неймовірно велику кількість можливих чинників впливу. Рухомість навколишнього середовища означає частоту змін цих чинників впливу. Невизначеність навколишнього середовища проявляється у неможливості точного прогнозування усіх чинників впливу та ступеня їхнього впливу на систему [5]. Ці теоретичні положення підтверджує такий емпіричний факт: жодній державі світу не вдалося забезпечити стабільний розвиток своєї економіки. Завжди періоди макроекономічного зростання перериваються економічними кризами того чи іншого характеру.

Чергування періодів економічного зростання і періодів економічного занепаду породило теорії циклічного розвитку макроекономічних систем. Емпірично встановлено, що в русі суспільного виробництва є роки, коли зростання загального обсягу виробництва відбувається швидкими темпами, а в інші роки - повільніше і навіть спостерігаємо спад. Такі коливання суспільного виробництва, які регулярно повторюються за певний проміжок часу, означають циклічний характер його розвитку. Тому ииклічність - це форма розвитку національної економіки і світового господарства як єдиного цілого, це рух від однієї макроекономічної рівноваги в масштабі економіки загалом до другої [2]. Класична схема ділового циклу охоплює чотири фази: криза, депресія, пожвавлення, піднесення.

Економічна криза має такі ознаки: 1) перевиробництво товарів порівняно 3 платоспроможним попитом на них; 2) значне скорочення обсягів виробництва; 3) зниження цін; 4) дефіцит вільних грошових засобів, необхідних для платежів; 5) біржовий крах та банкрутство підприємств, банків; 6) зростання рівня безробіття; 7) зниження рівня заробітної плати; 8) зменшення норми прибутку; 9) масове знищення товарів, устаткування тощо; 10) дезорганізація кредитної системи.

Депресія має такі ознаки: 1) "застій" виробництва; 2) низький рівень цін; 3) зменшення обсягів товарообігу; 4) низька відсоткова ставка; 5) ліквідація товарних надлишків, запасів. 
Фаза пожвавлення характеризується: 1) розширенням виробництва до рівня докризового періоду; 2) зростанням цін; 3) підвищенням норми прибутку; 4) зростанням зайнятості; 5) пожвавленням торгівлі; 6) посиленням оптимістичних очікувань.

Фаза піднесення має такі ознаки: 1) перевищення максимального обсягу виробництва докризового рівня; 2) швидке зростання зайнятості; 3) зростання заробітної плати та інших видів доходів; 4) кредитна експансія; 5) штучне стимулювання сукупного попиту, зумовлене очікуванням торговцями зростання цін та їх бажанням купити більше товарів за нижчими цінами; 6) зростання пропозиції, яка з часом перевищує попит і створює умови для нової кризи [6].

Сучасна економічна теорія визначає дві фази економічного (промислового) циклу: 1) рецесія, яка охоплює кризу та депресію; 2) піднесення, що містить пожвавлення та бум. Рецесія - це фаза економічного циклу, якій властиві падіння виробництва, що знаходиться між найвищою (бум) та найнижчою (дном) його точками, i зниження темпів зростання виробництва. За визначенням Національного бюро економічних досліджень США, рецесія - це період зниження рівня сукупного випуску, доходу, зайнятості, торгівлі, який триває від шести місяців до одного року і характеризується значним падінням у багатьох секторах економіки. Піднесення (розширення) виробництва - фаза, що знаходиться між найнижчою та найвищою точками циклу. Американські вчені [3, 9], досліджуючи циклічні коливання сучасної економіки, дійшли висновку, що динаміки рядів випуску і зайнятості показують довготермінове економічне зростання, яке називається зростаючим трендом, а коливання ділової активності навколо тренда утворюють економічні цикли [5].

Згідно зі сучасними уявленнями про діловий цикл, тренд розглядають як результат дії чинників, що зумовлюють довготермінове економічне зростання (приріст трудових ресурсів, науково-технічні зрушення тощо), а цикл - як тимчасове відхилення від цієї тенденції.

Російський учений Н. Д. Кондратьєв [6] у 1920-х роках опублікував праці, в яких показав існування довгих фаз зростання і спадання в часових рядах різних економічних показників для Англії, Франції та США. За його спостереженнями, період довгих хвиль становить приблизно 50 років. Н. Д. Кондратьєв [6] знайшов довгі цикли в динаміках цін, процентних ставок, зовнішньої торгівлі, обсягів виробництва вугілля і чавуну західних країн.

Національна економіка складається 3 великої кількості галузей та економічних агентів, які навряд чи синхронізують свої капітальні інвестиції. Тому пояснення довгих хвиль на рівнях національних економік чи світового господарства загалом на основі тільки динаміки капітальних інвестицій є неповним. Пізніше Н. Д. Кондратьєв [6] зауважив, що велика кількість відкриттів та винаходів у технологіях виробництва припадає на фазу спадання довгих хвиль, а використовувати їх у значних масштабах починають тільки на наступній фазі зростання. Тобто між моментом винаходження ефективної технології і до їі масового впровадження у виробництво може минути 25 років. Ці спостереження використав Дж. Шумпетер [11], який у своїй теорії інноваційного розвитку пояснював довгі хвилі Кондратьєва концентрацією інновацій в окремій галузі (кластері) в певний період часу. Наприклад, третю довгу хвилю пов'язують 3 розвитком металургії, електроенергетики і важкого машинобудування; четверту хвилю вважають ерою нафти, автомобілів і масового виробництва двигунів, літаків і електроніки. Сучасну п'яту хвилю послідовники Шумпетера [11] вважають ерою інформації та телекомунікацій. Припускають, що наступна шоста хвиля буде ерою біо- та нанотехнологій [13].

На основі уявлень Шумпетера [11] та його послідовників сформувалася теорія реальних бізнес-циклів (RBC - real business cycles). Згідно 3 цією теорією, циклічний розвиток макроекономічних систем зумовлений екзогенними випадковими змінами технологічної продуктивності [4]. При цьому ціни в економіці є гнучкими, тобто миттєво підлаштовуються під рівноважний попит та рівноважну пропозицію. Оскільки стохастичних коливань зазнає лише технологічний параметр у виробничих функціях RBC-моделей, то причиною макроекономічних коливань $€$ шоки зі сторони пропозиції.

Головними особливостями RBC-моделей є: 1) використання концепції репрезентативного агента для моделювання фірм та домогосподарств, що призводить до проблем узагальнення властивостей суб'єктів макроекономічної системи; 2) очевидні цільові функції фірм і домогосподарств, які оптимізуються в умовах обмеженості ресурсів та технологій; 3) зумовленість циклів зовнішніми шоками в технологічній ефективності, які зміщують виробничу функцію вверх або вниз; 4) використання концепцій раціональних очікувань, повних і зрівноважених ринків, відсутності інформаційної асиметрії; 5) використання додаткових ендогенних механізмів поширення первинних екзогенних шоків у продуктивності.

Зрозуміло, що значна кількість особливостей RBCмоделей потребує верифікації концепцій, які лежать в їхній основі. Тому RBC-моделі та RBC-теорія загалом піддаються значній критиці. Найсильнішими критичними зауваженнями є: по-перше, відсутність незалежних підтверджень доказів наявності великих технологічних шоків, які б відповідали за бізнес-цикли, а по-друге, $\mathrm{RBC}$-моделі мають складності з врахуванням динамічних особливостей обсягу виробництва через те, що додаткові ендогенні механізми поширення шоків $\epsilon$ загалом слабкими [13]. Найбільш послідовно критику RBCтеорії викладено в статті Л. Саммерса [12]. У цій статті Л. Саммерс критикує RBC-модель Прескота, проте всі зауваження не втрачають актуальності і для сучасні RBC-моделей. Зокрема, Саммерс ставить під сумнів точність і обгрунтованість вибору конкретних значень ряду параметрів у RBC-моделі. Наприклад, у моделі Прескота частка часу, яку домогосподарства витрачають на трудову діяльність, становить одну третю, хоча більшість статистичних досліджень на той час вказували, що цей параметр повинен становити одну шосту. Також є істотна неточність в оцінці реальної процентної ставки, яка в моделі Прескота встановлена на рівні $4 \%$, хоча, згідно зі статистичними даними США, середнє значення мало становити $1 \%$. Необгрунтований статистичними даними вибір ряду параметрів $є$ серйозною проблемою і для сучасних RBC-моделей. Більш фундаментальною проблемою в моделі Прескота є припущення щодо еластичності заміщення у пропозиції робочої сили. Згідно з цим припущенням, транзитні зміни в заробітній платі повинні сильно впливати на пропозицію робочої сили, що не відповідає емпіричним даним. 
Функція корисності, яку пропонує Прескот [9], передбачає, що збільшення реальної заробітної плати призводить до значного зменшення пропозиції робочої сили. При цьому досвід більшості розвинених країн показує, що більшість часу зростання реальної заробітної плати супроводжується і зростанням рівня зайнятості. Сьогодні RBC-теорія часто не може пояснити, які саме технологічні шоки спричинили конкретні економічні кризи.

Істотним недоліком RBC-моделей є також те, що їхні монетарні розширення погано описують емпіричну поведінку цінових коливань впродовж бізнес-циклу.

Отже, пояснення довгих хвиль Кондратьєва технологічними інноваціями, на нашу думку, є дуже спрощеним підходом, який не враховує низку чинників. Наприклад, на наш погляд, радикальна технологічна інновація не може бути впроваджена, якщо економіка не перебуває на достатньому рівні розвитку для сприйняття цієї інновації. Для впровадження інновації повинна бути готова відповідна інфраструктура. Окрім цього, собівартість розгортання виробництва на базі нової технології зменшується з часом під впливом ринкового механізму та ефекту масштабу, відповідно масове впровадження новітньої технології відбувається поступово. Тому в масштабах усієї економіки технологічна продуктивність від конкретної інновації зростає протягом значного часу. Оскільки технологічні інновації відбуваються в різних секторах у різні моменти часу і супроводжуються синергетичними ефектами різної тривалості, то важко уявити, що загальна технологічна продуктивність матиме періодичні коливання 3 тривалим періодом у 50 років. Згідно зі синергетичними підходами, коливання макроекономічних систем, на нашу думку, можуть бути аперіодичними або квазіперіодичними.

Неокласична школа, яка вважає, що економіка може ефективно функціонувати в умовах вільного ідеального ринку, наявність циклів пояснює, виходячи 3 концепції раціональних очікувань фірм та домогосподарств. На думку неокласиків [3], саме асиметрія інформації і відповідні помилки домогосподарств, фірм і фінансових посередників у сприйнятті монетарної та фіскальної політики уряду є причинами коливань в економіці. Неокласична модель економіки базується на чотирьох припущеннях: 1) концепція раціональних сподівань; 2) гіпотеза природного рівня безробіття; 3) припущення щодо неперервного зрівноваження ринку; 4) припущення про те, що макроекономічні агенти мають неповну інформацію. Теорія раціональних очікувань стверджує, що макроекономічні агенти точно прогнозують макроекономічні параметри, наприклад інфляцію, і відповідним чином змінюють свою поведінку для максимізації своїх цільових функцій. Як наслідок, монетарна та фіскальна політики уряду не можуть вплинути на реальні макроекономічні параметри. За таких умов економіка повинна розвиватися збалансованим шляхом із досягненням потенційного ВВП без коливань навколо тренду.

Згідно з неокласичною школою, макроекономічне регулювання уряду може мати вплив на реальні показники економіки тільки в короткотерміновій перспективі за умови того, що агенти з приватного сектору не зможуть правильно передбачити наслідки монетарної та фіскальної політики уряду. У довготерміновій перспективі агенти правильно передбачають наслідки макроекономічного регулювання, тому можна зробити висновки щодо теорії раціональних очікувань. Наявні не- окласичні моделі не можуть повністю відтворити явища бізнес-циклу. Тому висновок неокласичної школи про те, що цикли зумовлені несподіваними монетарними шоками, не $\epsilon$, на нашу думку, аргументованим. 3 положень неокласичної школи можна зробити висновок: якщо уряд впродовж тривалого часу не змінюватиме фіскальну політику і забезпечить прогнозовану монетарну політику, то економіка повинна розвиватися стабільно, без коливань.

Треба зазначити, що М. Фрідман та А. Шварц обгрунтували положення монетаризму на основі статистичних макроекономічних даних у США і Великобританії. Їхні економетричні моделі показали, що швидкість обігу грошей у рівнянні Фішера $є$ константою. Дослідження Д. Ф. Гендрі та Н. Р. Еріксона [4] показали, що рівняння М. Фрідмана та А. Шварц не витримують статистичних тестів. Один із провідних економістів сучасності П. Р. Кругман жорстко критикує монетаристські теорії, зокрема, для подолання сучасних фінансово-економічних криз, на його думку, повинні використовуватись кейнсіанські підходи. У своїй праці П. Р. Кругман [7] на прикладі фінансово-економічної кризи 2008-2009 рр. послідовно доводить свою позицію. Отже, сучасні неокласичні моделі не можуть достовірно описати механізми виникнення явищ ділового циклу. Сучасні вдосконалення неокласичних моделей однаково не дають змоги пояснити тривалість і магнітуду макроекономічних циклів, а також деякі емпіричні кореляції між макроекономічними змінними.

Неокейнсіанська школа виводить макроекономічні взаємозв'язки з мікроекономічної оптимізації поведінки економічних контрагентів і дещо зміненої концепції раціональних очікувань. У неокейнсіанській моделі в коротко- і середньотерміновій перспективах монетарна політика уряду, яка, наприклад, базується на правилі Тейлора [13], впливає на реальні макроекономічні показники, наприклад, реальний обсяг ВВП та рівень зайнятості. У довготерміновій перспективі, як і в неокласичній моделі, економіка досягає рівноважного стану. Коливання в макроекономічній системі неокейнсіанці пояснюють повільною зміною цін та заробітних плат, які не можуть миттєво підлаштуватися під нову кон'юнктуру ринку. Негнучкість цін зумовлюється або відсутністю інформації у частини продавців, або наявністю витрат на зміну цін (menu cost). Також неокейнсіанська концепція передбачає моделювання неідеальної конкуренції, яка також спричиняє негнучкість цін. Якщо через недосконалість ринку частина продавців не знає про новий рівень рівноважних цін, то негнучкість цін зазвичай моделюється за допомогою механізму Кальво. Цей спосіб моделювання не дає змоги відтворити мікроекономічні дані щодо реальної динаміки зміни цін, а це важливо для розуміння динаміки інфляції та ВВП. Таким чином неокейнсіанська модель відображає недосконалість ринкового механізму, який не може самостійно забезпечити досягнення потенційних рівноважних рівнів макроекономічної системи. У таких умовах макроекономічне регулювання повинно бути стабілізаційним у тому плані, що уряд може в коротко- i ceредньотерміновій перспективах впливати на реальні макроекономічні параметри, але розплатою за це $є$ потреба вибору між волатильністю ВВП та волатильністю інфляції. Тобто монетарна політика уряду може стабілізувати тільки або обсяг ВВП, або інфляцію. 
Висновки. Проведений аналіз літературних джерел дає змогу стверджувати, що на сьогодні неокейнсіанська концепція пояснення причин макроекономічних коливань $\epsilon$ найкращою з-поміж інших теорій. Отже, головними причинами макроекономічних коливань $є$ повільне підлаштування цін та заробітних плат до рівноважних рівнів і наявність ризиків у фінансовому механізмі макроекономічної системи. Однак, неокейнсіанські моделі не дають змоги пояснити довгі хвилі Кондратьєва.

У сучасних дослідженнях [8] науковці намагаються поєднати в одній моделі механізми поширення макроекономічної нестабільності як щодо попиту, так і щодо пропозиції. Тобто відбувається синтез неокейнсіанської та неокласичної концепцій. Проте цей синтез неокейнсіанських та неокласичних моделей також не дає змоги відтворити всі явища бізнес-циклу. Це наштовхує на думку, що в обох концепціях наявні фундаментальні припущення, які не дають змоги правильно змоделювати макроекономічну систему. На нашу думку, однією 3 причин недосконалості цих моделей $є$ практика моделювання функцій корисності домогосподарств, яка виходить 3 концепції раціональності вибору макроекономічного агента.

Сьогодні економічна наука не може чітко пояснити, змоделювати і спрогнозувати кризові явища в макроекономічних системах. Тому проведений нами аналіз літературних джерел показав, що не варто розраховувати на якісь детерміновані закономірності розвитку макроекономічних систем. Відповідно макроекономічне регулювання змушене мати адаптивний і стабілізаційний (контрциклічний) характери. Окрім цього, залишається не з'ясованим питання - чи можливо взагалі забезпечити сталий розвиток економіки без макроекономічних коливань.

\section{References}

1. Bazilinska, O. Ya. (2009). Macroeconomics. (2nd ed.). Kyiv: Center of educational literature, 442 p. [In Ukrainian].

2. Bilecka, L. V., Biletsskyi, O. V., \& Savych, V. I. (2009). The Economic theory: Political economy. Microeconomics. Macroeconomics. Kyiv: CUL, 688 p. [In Ukrainian].

3. Dornbusch, R., Fischer, S., \& Startz, R. (2004). Growth Theory: The Neoclassical Model. Macroeconomics, (pp. 61-75). (9th ed.). New York: McGraw-Hill Irwin.

4. Hendry David F., \& Ericsson Neil R. (1989). An Econometric Analysis of UK Money Demand in "Monetary Trends in the United States and the United Kingdom" by Milton Friedman and Anna J. Schwartz. Board of Governors of the Federal Reserve System. International Finance Discussion Papers, 355, 59.

5. Juk, M. O., \& Zdrok, V. V. (2014). Analysis of structure and functions of the system of housekeeping of Ukraine at macroeconomic level. Scientific Bulletin of UNFU, 24(9), 237-243. Retrieved from: https://nbuv.gov.ua/j-pdf/nvnltu_2014_24.9_45.pdf. [In Ukrainian].

6. Kondratev, N., D. \& Oparin, D. I. (1928). Large cycles of konyukturi: Lectures and their discussions are in Institute of economy. (1st ed.). Moscow: Institute of economy, 287 p. [In Russian].

7. Krugman, P. R. (2009). The Return of Depression Economics and the Crisis of 2008. W. W. Norton, $193 \mathrm{p}$.

8. Landmann, O. (2014). Short-Run Macro After the Crisis: The End of the "New" Neoclassical Synthesis. University of Freiburg. Department of International Economic Policy. Discussion Paper, 27, 22.

9. Prescott, Edward C. (1986). Theory Ahead of Business Cycle Measurement. Federal Reserve Bank of Minneapolis: Quarterly Review, 10(4), 9-22.

10. Prodanova, L. V., \& Litvin, V. V. (2012). Macroeconomics. Donetsk: DonNUET, 171 p. [In Ukrainian].

11. Schumpeter, J. A. (1939). Business Cycles. New York, NY: McGraw-Hill, $385 \mathrm{p}$.

12. Summers, Lawrence H. (1986). Some Skeptical Observations on Real Business Cycle Theory. Federal Reserve Bank of Minneapolis. Quarterly Review, 10(4), 23-27.

13. Taylor, J. B., \& Woodford, M. (Eds). (1999). Staggered Price and Wage Setting in Macroeconomics. Amsterdam, The Netherlands: Elsevier, 1009-1050 pp.

R. R. Kitc

Lviv University of Trade and Economics, Lviv, Ukraine

\section{CYCLIC CONFORMITIES TO LAW OF DEVELOPMENT OF MACROECONOMIC SYSTEMS}

Cyclic conformities to law of development of the macroeconomic systems are examined. A scientific analysis and generalization of looks of representatives of Keynesianism and neo conservatism is carried out on the basic problems of modern economic theory and practice, opening of their deposit, in development of economic science forming of economic policy of leading powers of the world and Ukraine going near classification of the economic systems. The author assumes that "the neo Keynesian concept of explaining the causes of macroeconomic fluctuations is the best among other theories." It is marked that in modern researches research workers try to connect in one model the mechanisms of distribution of macroeconomic instability both outside to demand and from the side of suggestion. That a synthesis of neo Keynesian is and neoclassical conceptions. However, this synthesis of neo Keynesian and also does not give neoclassical models possibility to reproduce all phenomena business of cycle. In both conceptions there are fundamental suppositions which do not allow correctly to model the macroeconomic system. A conclusion is done, that one of reasons of imperfection of these models there is practice of design of functions of utility of households, which goes out from conception of rationality of choice of macroeconomic agent. For today economic science is unable expressly to explain, to model and to predict the crisis phenomena in the macroeconomic systems. Therefore, conducted by us the analysis of literary sources retained that it does not cost to count on some determined conformities to law of development of the macroeconomic systems. Accordingly the macroeconomic adjusting is forced to carry adaptive and stabilizing character. For today economic science is unable expressly to explain, to model and forecast the crisis phenomena in the macroeconomic systems. Therefore, conducted by us the analysis of literary sources rotined that it does not cost to count on some determined conformities to law of development of the macroeconomic systems. Accordingly the macroeconomic adjusting is forced to carry adaptive and stabilizing character. In addition, a question is opened or it is possible in general to provide steady development of economy without macroeconomic vibrations.

Keywords: macroeconomic system; economic adjusting; market mechanism; finance and economic crisis. 